\title{
“After Thunder Comes Rain": The ECJ Finally Rules on the Boundaries of the EUMR Standstill Obligation
}

Luca Villani*

\begin{abstract}
In its judgment of 31 May 2018, case C-633/16, the European Court of Justice ruled on the preliminary questions referred by the Danish Maritime and Commercial Court in the context of a merger notified to the Danish Competition and Consumer Authority by KPMG DK and EY DK. The referring court asked the ECJ to clarify on the scope of the so-called standstill obligation imposed on the parties of a notifiable transaction by article 7 of the Council Regulation (EC) No. 139/2004 (EUMR).

The decision was long awaited, since after having imposed several fines for gun jumping practices in recent times, it is the first case ever in which the Court has been asked to take position on the matter through a preliminary ruling. As for substance, the European Court of Justice stated that article 7, paragraph 1 of the EUMR must be interpreted as meaning that a concentration is implemented only by a transaction which contributes to the change in control of the target undertaking.

In doing so, the Court gives a broad overview of the EU merger control system, recalling the fundamental concepts of concentration, control and standstill in order to give a systematic interpretation of the provisions at stake.
\end{abstract}

KEYWORDS: Merger control; concentration; EUMR; standstill; gun jumping.

\footnotetext{
* PhD at Roma Tre University, Rome, Italy; Lawyer at Latham \& Walkins, LLP. lucavillani07@ gmail.com.
} 


\section{Introduction}

On 31 May 2018, the European Court of Justice (ECJ or Court) ruled on the preliminary questions referred by the Sø-og Handelsretten (the Danish Maritime and Commercial Court, hereinafter the Referring Court) in case C- $633 / 16^{1}$ (Decision). ${ }^{2}$

The Decision was long awaited by scholars, professionals and market players, since for the first time the ECJ was asked to explore the boundaries of the so-called standstill obligation imposed on the parties of a notifiable transaction by article 7, paragraph 1 the Council Regulation (EC) No. 139/2004 of 20 January 2004 on the control of concentrations between undertakings (EUMR). ${ }^{3}$

As for substance, the Court held that article 7, paragraph 1 of the EUMR must be interpreted as meaning that a concentration is implemented only by a transaction which, in whole or in part, in fact or in law, contributes to the change in control of the target undertaking. ${ }^{4}$

The importance of the Decision is twofold.

First of all, from a merger control policy perspective, the Decision confirms the increasing interest shown by the European Union (EU) competition authorities in the enforcement of merger control procedural rules.

\footnotetext{
${ }^{1}$ Judgment of 31 May 2018, Ernst \& Young P/S v. Kokurrencerådet, C-633/16, EU:C:2018:371.

${ }^{2}$ For the first comments to the Decision, see Pietro Missanelli, "La portata dell'obbligo di standstill di cui all'art. 7, Regolamento (CE) 139/2004 nel periodo antecedente all'autorizzazione di una concentrazione tra imprese", Diritto del Commercio Internazionale 3 (2018): 765, and Michele Giannino, "Is it too early wrong? The Court of Justice of the EU clarifies the concept of gun-jumping", 2018, https://papers.ssrn.com/sol3/papers.cfm?abstract_id=3236909.

${ }^{3}$ Until the publication of the Decision, the topic had received only limited attention by the academic community.

Among the most significant contributions, see Stéphane Dionnet and Pauline Giroux, "Gun jumping”, 2017, https://www.skadden.com/-/media/files/publications/2017/01/gun_jumping. pdf; Francesco Carloni, "Electrabel v Commission \& COMP M.7184 Marine Harvest/Morpol: Gun-jumping and violation the merger standstill obligation in Europe", Journal of European Competition Law and Practice 5, no. 10 (2018): 693; Massimiliano Kadar, "Case T-704/14 - Marine Harvest v. Commission: On 'gun jumping' and public bids", Journal of European Competition Law and Practice 9, no 4 (2018): 239; Frederic Depoortere and Stephane Lelart, "The standstill obligation in the ECMR", World Competition 33, no. 1 (2010), 103; Bruno Alomar et al., "Electrabel/ CNR: The importance of the standstill obligation in merger proceedings", Competition Policy Newsletter 3 (2009), 58; James R. Modrall and Stefano Ciullo, "Gun-jumping and EU merger control”, European Competition Law Review 24, no. 9 (2003): 424; as well as the milestones John C. Cook and Cristopher S. Kerse, EC Merger Control (London: Sweet \& Maxwell), 144 and Nicholas Levy and Cristopher Cook, European Merger Control Law (New York: LexisNexis), 17.03.

${ }^{4}$ See Judgment of 31 May 2018, Ernst \& Young P/S v. Kokurrencerådet, C-633/16, EU:C:2018:371, paragraph 59 .
} 
Secondly, from a normative point of view, the Decision provides welcome guidance on one of the most controversial issues arising from the EUMR, i.e. the extent to which the merging parties can take preparatory steps to close a transaction before the clearance of the competent competition authority. The issue is of significant importance because it requires to strike the right balance between (a) the market players' need to carry out pre-merger activities and $(b)$ the legal requirements brought by the EUMR. Unsurprisingly, the Decision also offers a comprehensive overview of the EU merger control system and of its cornerstones, thus having a significant systematic value.

The present contribution is structured as follows: after a brief description of the facts of the case (see paragraph 2), I will provide an overview of its legal context (see paragraph 3), giving particular emphasis to the notion of concentration under the EUMR (see paragraph 3.1), to the so-called standstill obligation (see paragraph 3.2) and to the concept of gun jumping (see paragraph 3.3), which have been given significant importance by the ECJ in order to answer the questions referred. The last two paragraphs are dedicated to the description of the findings of the ECJ (see paragraph 4) and to some conclusive remarks (see paragraph 5).

\section{The facts of the case and the opinion of Advocate General Wahl}

The Referring Court sought a preliminary ruling by the ECJ in the context of an action for annulment brought by Ernst \& Young P/S against a decision of the Danish Competition Council (DCC). ${ }^{5}$

According to the DCC, Ernst \& Young, Ernst \& Young Europe LLP, Ernst \& Young Godkendt Revisionsaktieselskab, Ernst \& Young Global Limited and EYGS LLP (the "EY Companies") and KPMG Statsautoriseret Revisionspartnerselkab, Komplementarselskabet af 1. Januar 2009 Statsautoriseret Revisionsaktieselkab and KPMG Ejendomme Flinthom K/S (the "KPMG DK Companies") had infringed paragraph 12c(5) of the Danish law on competition, which prohibits the implementation of a merger prior to its approval by the DCC in a similar way as article 7 EUMR.

Coming to the merits of the case, by agreement concluded in November 2013 (Agreement) the KPMG DK Companies and the EY Companies decided to merge. According to the parties' preliminary assessment, the

\footnotetext{
${ }^{5}$ See Decision 14/07180 SAM/MAN/JKK/CWA, https://www.en.kfst.dk/media/3301/20141217overtraedelse-af-praeimplementeringsforbud1.pdf (Danish language only).
} 
merger at stake did not have a Community dimension within the meaning of the EUMR, but had to be notified to the competent Danish authorities.

At the time of the conclusion of the Agreement, the KPMG DK Companies were part of an international network of independent auditing firms (KPMG International) pursuant to a cooperation agreement which harmonised how the KPMG DK Companies operated inside KPMG International. ${ }^{6}$ In implementation of the Agreement, on 18 November 2013 the KPMG DK Companies announced that, with a view to the merger with the EY Companies, they were withdrawing from KPMG International. The termination of the cooperation agreement was not in itself notified to any competition authority.

On 13 December 2013, the Danish Competition and Consumer Authority was notified of the merger between the KPMG DK Companies and the EY Companies, which was then cleared on 28 May 2014. ${ }^{7}$

Following the clearance of the transaction, the DCC declared that the KPMG DK Companies had violated the prohibition of implementing a concentration prior to its approval by giving notice to terminate the cooperation agreement before obtaining a formal clearance. According to the DCC, the notice of termination of the cooperation agreement could well amount to an early implementation since it was (a) merger-specific, (b) irreversible and (c) likely to have market effects in the period between the notice of termination itself and the approval of the merger.

Ernst \& Young brought an action for annulment of the DCC decision before the Referring Court. Since the Danish rules on merger control are based on the EUMR and the DCC's decision essentially referred to the

\footnotetext{
${ }^{6}$ More specifically, as explained in Judgment of 31 May 2018, Ernst \& Young P/S v. Kokurrencerådet, C-633/16, EU:C:2018:371, paragraphs 12 and 13, under the cooperation agreement the KPMG DK Companies had the exclusive right to be included in KMPG International in Denmark and to use the trademarks of KPMG International for marketing purposes in that Member State. Moreover, the cooperation agreement also contained provisions on the allocation of customers, the obligation to serve clients from other Member States and the annual compensation for participation in the network. In addition, it provided that the participating auditing firms could not conclude commercial contracts such as partnerships or joint ventures. It also established a voluntary and integrated cooperation between the participating auditing firms, under which the firms operated according to the same standards and norms and presented themselves to clients as a combined network, although each of them was an autonomous and independent undertaking for the purposes of competition law.

${ }^{7}$ See "Denmark: Merger in the audit industry approved with commitments", Danish Competition and Consumer Authority. https://www.en.kfst.dk/nyheder/kfst/english/decisions/20140528-denmark-merger-in-the-audit-industry-approved-with-commitments/.
} 
European Commission's decision-making practice and to the case-law of the ECJ, the referring Court considered that the interpretation of article 7, paragraph 1 of the EUMR was relevant for the case and therefore asked for clarifications from the ECJ.

As far as the position of the parties is concerned, EY argued that the termination of the cooperation agreement could not fall within the prohibition of article 7 EUMR since it could not in itself amount to a concentration under the EUMR. In EY's view, such an interpretation would not hamper the effectiveness of the European merger control system, since the possible effects on competition of measures falling outside the scope of the standstill obligation could still be subject to competition law by means of articles 101 and 102 TFEU. At the opposite, the Danish Government ${ }^{8}$ and the European Commission adopted a more conservative approach, arguing that "the standstill obligation cannot be restricted to measures which, in themselves, entail an actual change of control but must include any measures which, given the circumstances, are apt to restrict or render more difficult the effective ex ante merger control".

Advocate General (AG) Nils Wahl delivered his Opinion on 18 January $2018 .^{10}$

Interestingly enough, the AG took distance from the reasoning of the Referring Court with specific regard to the relevance it attached to the three criteria of merger-specificity, irreversibility and market effects. Indeed, the AG argued that trying to enumerate general criteria would pose the risk of excluding certain measures from the notion of standstill obligation, to the detriment of an effective merger control system.

As far as the criteria submitted by the DCC are concerned, according to the AG merger specificity is a prerequisite for - and not a criterion of - application of the standstill obligation. Such a criterion might make it easier to exclude certain measures which patently have nothing to do with the implementation of a concentration, but "does not provide any added value as without it the Commission's power under the EUMR would not

\footnotetext{
${ }^{8}$ Interestingly enough, the Danish government supported its position referring to the findings of the General Court in Electrabel v. European Commission regarding the importance of an ex ante merger control system, which will be described in detail under paragraph 3.3.

${ }^{9}$ See Opinion of AG Nils Wahl delivered on 18 January 2018, Ernst \& Young P/S v. Kokurrencerådet, C-633/16, EU:C:2018:23, paragraph 41.

${ }^{10}$ See Opinion of AG Nils Wahl delivered on 18 January 2018, Ernst \& Young P/S v. Kokurrencerådet, C-633/16, EU:C:2018:23.
} 
even come into question". ${ }^{11}$ The same applies to the irreversibility criterion, which according to the AG may be "excessively speculative" and would run contrary to some provisions of the EUMR. Indeed, article 8, paragraph 5, letters $a$ and $c$ of the EUMR empowers the Commission to order the reversal of measures which implement a concentration prematurely: it would seem contradictory for the Commission to have such a power if the application of the standstill depended on the irreversibility of a measure. Finally, as far as the creation of market effects is concerned, according to the AG not only do commercial measures almost invariably have some effect on the market, but a market effects criterion would inevitably overlap with the merits of the assessment of the transaction by the Commission. Quoting the AG, "if such a criterion were relevant, it would [...] make the standstill obligation [...] a type of automatic injunction procedure". ${ }^{12}$

In light of the above, according to the AG the scope of the standstill obligation shall be demarcated by means of a negative definition. From this point of view, the starting point for correctly shaping the notion of standstill obligation should be the notion of concentration, given that article 7 of the EUMR expressly refers to a "concentration with an EU dimension", as defined in article 1 thereof. Given that a concentration is the acquisition of the possibility of exercising decisive influence on a target undertaking, the standstill obligation cannot apply to merely internal preparatory measures preceding a concentration..$^{13}$ Only measures that are intrinsic to a concentration must be caught. This is further confirmed by the fact that interpreting the standstill obligation without linking it to the concept of concentration would pose the risk that certain measures lying in the "periphery of a concentration" although not "inextricably linked" ${ }^{14}$ to the transfer of control would be caught thereby. Conversely, if the reach of that grey area were greater than the scope of the concept of a concentration, that would imply extending that obligation beyond the scope of the EUMR as expressed in article 1 thereof and going beyond what is necessary to maintain an effective merger control.

\footnotetext{
${ }^{11}$ See Opinion of AG Nils Wahl delivered on 18 January 2018, Ernst \& Young P/S v. Kokurrencerådet, C-633/16, EU:C:2018:23, paragraph 49.

${ }^{12}$ See Opinion of AG Nils Wahl delivered on 18 January 2018, Ernst \& Young P/S v. Kokurrencerådet, C-633/16, EU:C:2018:23, paragraph 55.

${ }^{13}$ See Opinion of AG Nils Wahl delivered on 18 January 2018, Ernst \& Young P/S v. Kokurrencerådet, C-633/16, EU:C:2018:23, paragraph 63.

${ }^{14}$ See Opinion of AG Nils Wahl delivered on 18 January 2018, Ernst \& Young P/S v. Kokurrencerådet, C-633/16, EU:C:2018:23, paragraph 68.
} 
In light of the above, the $\mathrm{AG}$ concluded that the obligation laid down by article 7 EUMR does not affect measures like the one carried out by the parties to the transaction at stake which, although taken in connection with the process leading to a concentration, precede and are severable from the measures actually leading to the acquisition of the possibility of exercising decisive influence on a target undertaking. ${ }^{15}$

\section{The legal context}

As anticipated in paragraph 1 and confirmed by the Opinion of the AG (see paragraph 2), in order to gain a better understanding of the rationale underpinning the Decision it is useful to briefly recall certain aspects of EU merger control law, namely the concept of concentration under the EUMR (see paragraph 3.1), the so-called standstill obligation (see paragraph 3.2) and the concept of gun jumping (see paragraph 3.3).

\subsection{The notion of concentration under the EUMR}

As is well known, EU merger law mainly stems from two sources: the EUMR $^{16}$ and the European Commission's Consolidated Jurisdictional Notice (Jurisdictional Notice), ${ }^{17}$ which describes the practice of the European Commission (Commission) in regard to the scope of application of the EUMR. ${ }^{18}$

\footnotetext{
${ }^{15}$ See Opinion of AG Nils Wahl delivered on 18 January 2018, Ernst « Young P/S v. Kokurrencerådet, C-633/16, EU:C:2018:23, paragraph 88.

${ }^{16}$ The Commission recently defined the EUMR as a "major overhaul", see European Commission, White Paper towards more effective EU merger control, COMP(2014) 449 final, July 9, 2014, http:// ec.europa.eu/competition/consultations/2014_merger_control/mergers_white_paper_en.pdf, 4 .

${ }^{17}$ European Commission, Commission Consolidated Jurisdictional Notice under Council Regulation (EC) No. 139/20017 on the control of concentrations between undertakings, 2008/C 95/01, April 16, 2008, https://eur-lex.europa.eu/legal-content/EN/ALL/?uri=CELEX\%3A5200 8 XC0416\% $2808 \% 29$.

${ }^{18}$ For the sake of completeness, it is worth recalling that the Treaty establishing the European Community, as well as the Treaty on European Union (TEU) and the Treaty on the Functioning of the European Union (TFEU) do not contain specific provisions applying competition law to concentrations, unlike the Treaty that established the European Coal and Steel Community, which required certain transactions in the coal and steel sectors to be notified to the Commission.

The European Commission's view, endorsed by the European Court of Justice in the Continental Can judgment, was in the sense that articles 101 and 102 TFEU were not sufficient to apply competition law to mergers and therefore the Commission needed an ad hoc legal instrument to control concentrations leading to the creation or strengthening of a dominant position.

After an intense debate, the first merger regulation was adopted in December 1989 and came into force in 1990.
} 
As underlined by the European Commission, the EUMR has the fundamental objectives of "protecting consumers against the effects of monopoly power (higher prices, lower quality, lower production, less innovation)"19 and of addressing "all potential sources of possible harm to competition, and thus consumers, caused by concentrations or corporate restructuring". ${ }^{20}$

The EU merger policy as arises from the EUMR and the Jurisdictional Notice is based on three key assumptions. ${ }^{21}$ First, as declared under recital 3 of the EUMR, "the completion of the internal market and of economic and monetary union, the enlargement of the European Union and the lowering of international barriers to trade and investment will continue to result in major corporate reorganisations, particularly in the form of concentrations". Second, as continues recital 4 of the EUMR, such reorganisations are welcome "to the extent that they are in line with the requirements of dynamic competition and capable of increasing the competitiveness of European industry, improving the conditions of growth and raising the standard of living in the Community". Finally, in light of the above, "it should be ensured that the process of reorganisation does not result in lasting damage to competition". This is the reason why EU law must include provisions governing concentrations which may "significantly impede effective competition in the common market or in a substantial part of it". ${ }^{22}$

That said, as recalled by the AG, the starting point for correctly shaping the notion of standstill obligation has to be the notion of concentration. But what exactly is a concentration pursuant to the EUMR?

Generally speaking, as recently recalled by the OECD, ${ }^{23}$ the definition of what constitutes a concentration can be based on objective or economic criteria. Most jurisdictions have opted for more economic criteria, according to which a concentration is deemed to arise when the transaction leads to the acquisition by a company of single or joint control over another.

\footnotetext{
${ }^{19}$ European Commission, XXXI Report on Competition Policy 2001, 2002, http://ec.europa.eu/ competition/publications/annual_report/2001/en.pdf, paragraph 252.

${ }^{20}$ EC, White Paper, 2014: 4.

${ }^{21}$ Levy and Cook, European Merger Control Law, 1-1.

${ }^{22}$ See recital 5 of the EUMR.

That is also the reason why, as clearly stated in the European Commission XX Report on Competition Policy, paragraph 20, the Commission has always viewed the EUMR as "a vital additional instrument [...] to ensure a system of undistorted competition in the Community".

${ }^{23}$ See OECD, Suspensory Effects of Merger Notifications and Gun Jumping, 27-28 November 2018, DAF/COMP(2018)11, 6 .
} 
This kind of definition is more substantial in nature and may well end up being broader. On the other hand, objective criteria give relevance to factors such as a certain shareholding in the target firm: this has "the positive consequence of being easy to assess and thus leave little room for unintentionally failing to notify". ${ }^{24}$

As recalled by AG Wahl (see paragraph 2), within the EU legal order the definition of what constitutes a concentration is provided by article 3 of the EUMR and is further explained in the case law of the ECJ and in Part B of the Jurisdictional Notice. Under article 3 of the EUMR, a concentration shall be deemed to arise where a change of control on a lasting basis "results from: (a) the merger of two or more previously independent undertakings or parts of undertakings, or (b) the acquisition, by one or more persons already controlling at least one undertaking, or by one or more undertakings [...] of direct or indirect control of the whole or parts of one or more other undertakings".

The concept of merger ${ }^{25}$ (which is the most relevant for the purposes of the present contribution, given the nature of the transaction involving the KPMG DK Companies and the EY Companies) is not defined in the EUMR, although the Jurisdictional Notice explains that a merger occurs where two or more independent undertakings "amalgamate in a new undertaking and cease to exist as separate legal entities". ${ }^{26} \mathrm{~A}$ merger may also occur where one undertaking is absorbed by another, the latter retaining its legal identity while the former ceases to exist as a distinct legal entity. ${ }^{27}$ In the absence of a legal merger, a merger within the meaning of the EUMR may also occur where the combination of the activities of previously independent undertakings results in the creation of a single economic unit. ${ }^{28}$

\footnotetext{
${ }^{24}$ OECD, Suspensory Effects of Merger Notifications and Gun Jumping, 7.

${ }^{25}$ For further readings on mergers, see Richard Whish and David Bailey, Competition Law (Oxford: Oxford University Press, 2015) and the Italian works of Piero Fattori and Mario Todino, La Disciplina della Concorrenza in Italia (Bologna: Il Mulino, 2010) and Matteo Beretta and Marco d'Ostuni, Il Sistema del Controllo delle Concentrazioni in Italia (Torino: Giappichelli, 2018).

${ }^{26}$ EC, Jurisdictional Notice, paragraph 9.

${ }^{27}$ On the other hand, a merger within the meaning of the EUMR is not deemed to occur where a target company is merged with a subsidiary of the acquiring company, so that the parent company acquires control of the target company.

${ }^{28}$ EC, Jurisdictional Notice, paragraph 9.

See also Case No. COMP/M.2510 - Cendent/Galileo; Case No. COMP/M5529, Oracle/Sun Microsystems, and Case No. COMP/5611 Agilent/Varian.
} 
In light of the above, it should be clear why AG Wahl underlined that the notion of concentration is closely linked with the one of control.

According to the provisions of the EUMR and of the Jurisdictional Notice, the notion of control which is relevant for the purposes of establishing whether there is a concentration is quite broad. More specifically, under article 3, paragraph 2 of the EUMR, control is defined as the possibility of exercising a "decisive influence" on an undertaking, by means of "rights, contracts or any other means, either separately or in combination and having regard to the considerations of fact or law involved". The Commission has interpreted the notion of decisive influence broadly to include positive rights to manage another undertaking, as well as veto rights over another undertaking's commercial policy. Therefore, control can exist on a legal (de jure) or a factual (de facto, see further paragraph 3.2) basis. ${ }^{29}$ Control may be exercised solely by a single undertaking or jointly, by two or more undertakings. The notion of control under the EUMR may differ from notions of control developed in other areas of EU legislation, including with respect to prudential rules, taxation, air transportation or media. Accordingly, the interpretation of control in other areas of EU law is not necessarily decisive in analysing control under the EUMR. ${ }^{30}$ Control under the EUMR may also differ from provisions of national legislation, including national competition law. ${ }^{31}$ As a result, "different legal or factual assessments by different authorities, each acting in accordance with their own powers, cannot always be avoided, especially if these authorities act on a different legal basis". ${ }^{2}$

If a certain transaction amounts to a concentration under the EUMR and meets the turnover thresholds set forth by the EUMR, that transaction will fall within the ex ante merger control system designed by the EUMR. ${ }^{33}$

This may be the case in particular where two or more undertakings, while retaining their individual legal personalities, contractually establish a common economic management or operate as a dual-listed company. A prerequisite for the determination of a single economic unit is the existence of a permanent, distinct management, see EC, Jurisdictional Notice, paragraph 10.

${ }^{29}$ EC, Jurisdictional Notice, paragraph 16.

${ }^{30} \mathrm{EC}$, Jurisdictional Notice, paragraph 23.

${ }^{31}$ EC, Jurisdictional Notice, paragraph 22.

${ }^{32}$ See Commission Decision of 26 June 2002, declaring a merger to be compatible with the common market and the EEA Agreement (Case COMP/M.2650 - Haniel/Cementbouw/JV (CVK)).

${ }^{33}$ As recalled by the OECD, Suspensory Effects of Merger Notifications and Gun Jumping, 5, most merger control regimes, just like the EU, adopt ex ante merger control, typically coupled with standstill obligations. There are three reasons for the provision of pre-merger notification obligations. First of all, they aim at ensuring that mergers do not have negative effects on market struc- 
In this regard, it is worth recalling that the notion of control is used both to determine whether a given operation is notifiable under the EUMR and to establish which entities should be taken into account for purposes of assessing the revenues of those undertakings directly affected by a concentration, which in turn determines whether the EUMR's jurisdictional thresholds are met. ${ }^{34}$

The difficulties that businesses face when trying to ascertain their premerger notification duties are amplified by the fact that even though similar concepts for transactions, thresholds and turnover calculation and exemptions will be used in most jurisdictions, there are still significant variations in the legal rules and in their application between jurisdictions. For example, the same transaction can be considered a reportable minority stake in one jurisdiction, but not in another.

Once it is established that a certain transaction amounts to a concentration pursuant to the EUMR and that it is subject to mandatory notification for pre-merger control, the standstill obligation provided by article 7 EUMR will be triggered.

\subsection{Article 7 of the EUMR}

Article 7, paragraph 1 of the EUMR, named "suspension of concentrations", states that a concentration with a Community dimension shall not be implemented (i.e. its implementation must be suspended) either "before its notification or until it has been declared compatible with the common market". Article 7, paragraph 2 of the EUMR provides for some limited exemptions from the application of paragraph 1 for the cases of public bids

tures in the interim period. Secondly, it avoids the potentially difficult untangling of assets and business relationships, and, finally, it aims at preventing illicit pre-merger information exchanges. Put differently, the rationale behind pre-merger notification is to ensure that the merging parties remain independent market players until the competent antitrust authority has had the chance to review the transaction, thus preventing competition problems before they arise as fixing them after the closing of the transaction may be much harder. On the other hand, one should not forget that merger activity is mostly beneficial, as is made clear by the vast majority of mergers which are approved without conditions everywhere in the world. Mergers are a means for companies to compete and to realise welfare-enhancing efficiencies. Delaying merger implementation thus imposes costs not only on merging parties, but to society more generally.

${ }^{34}$ Notification thresholds are used to identify the transactions that have sufficient material weight and nexus to a given jurisdiction and should be notified for merger control. Commonly used criteria are turnover and/or assets or thresholds, along with the value of the transaction and market share thresholds. Additional criteria are sometimes adopted. 
or of a series of transactions in securities, by which control is acquired from various sellers.

As ultimately recalled by AG Wahl in the case at issue, the function of this obligation - more commonly referred to as "standstill obligation" or as the imposition of a "waiting period" - is "to deter undertakings from implementing concentrations prematurely, pending assessment by the competition authorities, and to reduce the risk that a concentration will have to be undone in case it is not approved". ${ }^{35}$ Put differently, article 7, paragraph 1 of the EUMR pursues the objective of enhancing the efficiency of the whole merger control process, as it aims at protecting competition, safeguarding the independence and autonomy of the merging parties, and facilitating an eventual break-up that may be ordered at the end of the merger review process.

The usefulness of such a tool is confirmed by the fact that the majority of the merger control systems across the world make use of it. ${ }^{36}$ Nevertheless, exceptions exist: for instance, in the European Union this is the case in Italy, ${ }^{37}$ Latvia and the United Kingdom. As confirmed by AG Wahl, that indicates that "while the standstill obligation might be useful, it would seem excessive [...] to classify it as an indispensable tool for merger control". ${ }^{38}$

\footnotetext{
${ }^{35}$ See Opinion of AG Nils Wahl delivered on 18 January 2018, Ernst \& Young P/S v. Kokurrencerådet, C-633/16, EU:C:2018:23, paragraph 35.

${ }^{36}$ For example, in the USA section 7A HSR imposes the obligation to notify and prescribes a waiting period of 30 days (which can be extended by another 30 days) during which the merging parties are prohibited from shifting beneficial ownership over the target to the acquiring party.

The Japanese anti-monopoly act requires prior notification of merger plans above certain turnover thresholds, including minority acquisitions. Notifying parties are prohibited from implementing mergers for 30 days after the notification has been received by the local competition authority. Also Canada and Brazil have standstill obligations.

${ }^{37}$ In Italy, pre-merger notification obligations do not trigger a suspension of the merger, which can be implemented prior to clearance. When a second phase investigation is opened, the Italian Competition Authority may issue an order not to implement the transaction if the latter raised serious competition concerns.

${ }^{38}$ See paragraph 35 of the Opinion.

Levy and Cook, European Merger Control Law, 7.1 describe the suspension of notifiable mergers pending approval by the Commission as one of the "principal procedural rules" of the European Union merger control system.

On the other hand, during a speech given on 10 March 2016, reining the EU merger control system, available at https://ec.europa.eu/commission/commissioners/2014-2019/vestager/announcements/refining-eu-merger-control-system_en, Commissionaire Vestager declared that in cases of gun jumping "any damage to competition might already be done before we can take our decision. So we keep a very close eye on whether companies are complying with the procedural rules".
} 
Because of its broad formulation, article 7, paragraph 1 of the EUMR has often given rise to uncertainties like the one which gave rise to the Decision. As noted, ${ }^{39}$ one of the most controversial issues regards the acquisition of minority shareholding, which may well raise questions under article 7 EUMR. In order to better understand all the potential implications of the Decision, it is worth recalling some of the issues related to minority shareholding acquisitions.

Indeed, minority shareholdings may, in some situations, confer de facto control; their acquisition can be considered as a partial implementation of a broader concentration or as interrelated with another transaction. As far as de facto control is concerned, according to the Jurisdictional Notice the main assessment criterion is the likelihood of achieving a majority at the target's shareholders' meeting, given the level of its shareholding and the evidence resulting from the presence of shareholders in the shareholders' meetings in previous years. ${ }^{40}$ The Commission usually considers voting patterns at shareholders' meetings held in the last three to five years. Other factors taken into account by the Commission may be the dispersion of the remaining shares, the structural, economic or family links of important shareholders with the large minority shareholders, and the nature of other shareholders' interests (whether strategic or purely financial). ${ }^{41}$ As other authors observed, ${ }^{42}$ a review of the cases in which the Commission concluded that a minority shareholding conferred de facto control shows that a large number of different situations can lead to de facto control and that it is certainly not always easy to determine whether or not control is acquired. ${ }^{43}$ Determining whether a minority shareholding will confer $d e$ facto control is therefore a difficult exercise.

In principle, as long as minority shareholding does not confer control, there is no need for notification. In terms of article 7, paragraph 1 EUMR

\footnotetext{
${ }^{39}$ Deporteere and Lelart, "The standstill obligation in the ECMR", 105.

${ }^{40}$ EC, Jurisdictional Notice, paragraph 59.

${ }^{41}$ EC, Jurisdictional Notice, paragraph 59.

${ }^{42}$ Deporteere and Lelart, "The standstill obligation in the ECMR", 105.

${ }^{43}$ See inter alia Commission Decision of 05/05/2008 declaring a concentration to be compatible with the common market and the EEA Agreement (Case No. Comp/M.4956 - STX/Aker Yards); Commission Decision of 23 April 1997 declaring a concentration to be compatible with the common market and the functioning of the EEA Agreement (Case No. IV/M.754 - Anglo American Corporation/Lonrho); Commission Decision, declaring a concentration to be compatible with the common market (Case No. IV/M.906 - Mannesmann / Vallourec); and Commission Decision declaring a concentration to be compatible with the common market (Case No. COMP/M.4336 - MAN/Scania).
} 
consequences, this means that the acquisition of minority shareholdings can be implemented without any obligation to suspend the transaction pursuant to the obligation provided therein. Problems arise because, as is well known, the Commission may, in certain circumstances, consider a group of interrelated transactions as one single merger operation where the transactions at issue are interdependent in such a way that none of them would be carried out without the others and that the result consists in conferring on one or more undertakings direct or indirect economic control over the activities of one or more undertakings. Such an approach is obviously justified with the need to prevent circumvention of the merger rules by artificially creating interrelated transactions. Whether or not the merger rules are artificially circumvented is a case-by-case exercise. It follows that, as a general matters, it is not at all clear what companies can and cannot do before obtaining approval from the Commission under the EUMR. Before the Decision, the almost non-existent case law on pre-closing practices and gun jumping provided basically no guidance.

That is (one of the reasons) why the Decision is so significant.

That is why it may be useful to briefly go into the so-called gun jumping issue.

\subsection{Gun jumping}

"Gun jumping" refers to infringements of both the obligation to notify a certain transaction and the standstill obligation. It follows that the use of the concept of "gun jumping" may well lead to confusion insofar as it refers to different infringements. This is due to the fact that, as seen before, most jurisdictions that adopt mandatory notification also impose a standstill obligation or waiting period on the merging parties.

This ambiguous linguistic scenario is further complicated by the fact that some sources ${ }^{44}$ distinguish "substantive" gun jumping from "procedural" gun jumping. From this perspective, procedural gun jumping occurs in cases of implementation of a transaction without prior notification where notification is mandatory ${ }^{45}$ as well as in cases of pre-closing conducts in

\footnotetext{
${ }^{44}$ Dionnet and Giroux, Gun Jumping and OECD, Suspensory Effects of Merger Notifications and Gun Jumping.

${ }^{45}$ For some of the most recent cases, see Decision of the Spanish Comisiòn Nacional de los Mercados y la Competencia, 31 July 2014, Essilor, Case SNC/DC/0035/14, in which although the notification was made seven months after the execution of the merger, the Spanish competition authority accepted the argument brought by the parties pursuant to which the failure to notify had
} 
violation of the relevant standstill obligations by partly or fully putting a merger into effect before the end of the standstill period $;{ }^{46}$ finally, substantive gun jumping occurs in case of violations of prohibitions of horizontal anti-competitive agreements.

As already seen with regard to the possible meeting of merger notification thresholds, uncertainty may also arise with regard to what amounts to gun jumping. This may produce negative effects on transactions, since it may cause delays in the implementation of mostly pro-competitive transactions, raise transaction costs and create incentives for businesses to test the limits of gun jumping prohibitions and circumvent standstill rules. These costs need to be balanced against the benefits of ex ante merger control and of delaying merger implementation for the duration of the standstill obligation. This also forces competition authorities to dedicate resources to the monitoring and prosecution of procedural matters. ${ }^{47}$

As far as the enforcement at the EU level of such obligations is concerned, ${ }^{48}$ at present the Commission has only rarely imposed fines

been caused by a wrong calculation of their market share (as Spanish merger control thresholds partially involve market share calculations).

${ }^{46}$ As far as procedural gun jumping is concerned, the failure to notify a transaction is surely the most straightforward gun jumping offense. This may happen because a mandatory notification is simply overlooked or forgotten, or for failure to identify a duty to notify or as an international lack of notification in order to speed up the merger process or avoid competition scrutiny. This will usually only occur when it is expected that a competition agency will never find out and bother to impose sanctions, or when the merger control agency is seen as lacking effective enforcement powers. In addition, many agencies may decide to give lenient treatment to first-time offenders and to abstain from prosecuting in a number of cases.

${ }^{47}$ OECD, Suspensory Effects of Merger Notifications and Gun Jumping, 10.

It is noteworthy that some cases of failure to notify actually raised competition concerns. This was the case inter alia in Germany ZA Raiffeisen/Wurth, decision of the Bundeskartellamt Tatigkeitsbericht 2009/10, 68 and Germany Marienhaus/Barmherzige Bruder Trier, Bundeskartellamt Fallbeicht B3-32/11 and B3-49/12 of 16 April 2013.

${ }^{48}$ Of course the Commission is not the only competition authority which has shown interest in this kind of cases. For example, the French competition authority addressed the matter in Decision of 8 November 2016, n.16-D-24 relative à la situation du groupe Altice au regard du II de l'article L.430-8 du code du commerce and the same did the Bundeskartellamt, decision of 31 March 2015, B2-96/14.

For other examples, see OECD, Suspensory Effects of Merger Notifications and Gun Jumping, 20. 
for cases of "procedural gun jumping". This was the case in 2009, 2014 and 2018, when the Commission respectively fined Electrabel, ${ }^{49}$ Marine Harvest ${ }^{50}$ and Altice. ${ }^{51}$

${ }^{49}$ See Judgment of 12 December 2012, Electrabelv. European Commission, T-332/09, EU:T:2012:672,
and Judgment of 3 July 2014, Electrabel v. European Commission, C-84/13, EU:C:2014:2040. For
the purposes of the present contribution, suffice it to say that in 2009 the Commission fined the
Belgian electricity producer for failing to notify the acquisition of a minority stake in Compagnie
Nationale du Rhone. More specifically, between June and December 2003 Electrabel increased its
share in the target undertaking from approximately $17 \%$ to $49.95 \%$ and $47.92 \%$ of voting rights. In
2007 , Electrabel sought the Commission's view on whether this shareholding could be considered
to confer de facto sole control over the target undertaking. After prolonged discussions with the
Commission, Electrabel finally notified the transaction in March 2008. After an ad-hoc investiga-
tion, in 2009 the Commission concluded that Electrabel had acquired control in 2003, thus trig-
gering the EUMR filing requirement. In establishing whether control had been acquired or not,
the Commission took into account a number of factors including Electrabel's shareholding in the
target undertaking, the dispersed nature of the shareholders, many of whom did not attend general
meetings, and the fact that Electrabel had a majority on the target's board and a preferential right
for further shares. The General Court upheld the decision rejecting Electrabel's argument that its
conduct merely amounted to a procedural violation and found that the failure to file a reportable
transaction was a serious violation of EU competition law. In 2014, Electrabel's appeal to the ECJ was rejected in its entirety, largely on procedural grounds.

${ }^{50}$ See Judgment of 26 October 2017, Marine Harvest ASA v. European Commission, T-704/14, EU:T:2017:753. An appeal is currently before the General Court in T-704/14. Marine Harvest was fined for failure to notify the acquisition of sole control over Morpol ASA by means of an acquisition of a $48.5 \%$ shareholding. More specifically, Marine Harvest acquired $48 \%$ of the target undertaking in 2012 and subsequently launched a public offer and acquired 87.1\% of Morpol's shares in 2013. The merger was (conditionally) cleared, but then the Commission fined Marine Harvest on the grounds that it had already acquired de facto control over Morpol as a result of the 2012 transaction, thus breaching the standstill obligation.

Indeed, the Commission held that the two transactions could not be considered as one single unitary transaction, and that the acquisition of the $48.5 \%$ shareholding enabled Marine Harvest to enjoy a stable majority at the shareholders' meetings as a consequence of the wide dispersion of the remaining shares (and previous attendance rates at these shareholders' meetings), and therefore gave Marine Harvest de facto control over Morpol.

${ }^{51}$ In July 2017, the Commission fined Altice for implementing the acquisition of sole control over PT Portugal before notification or approval by the Commission. More specifically, according to the Commission certain provisions of the purchase agreement entered into by the parties brought Altice to acquire the "legal right to exercise decisive influence over PT Portugal, for example by granting Altice veto rights over decisions concerning PT Portugal's ordinary business". This decisive influence was indeed exercised in the context of strategic decisions of the target like marketing campaigns. In this context, the Commission emphasised that a breach of the standstill obligation may result from obtaining the ability to exercise a decisive influence or the actual exercise of decisive influence. As noted in the OECD report, an interesting aspect of the case is the close analysis of the purchase agreement and the conclusions of what constitutes veto rights concerning PT Portugal's ordinary business, constituting the ability to exercise control. While the Commission fully acknowledges that "clauses determining the conduct of a target between signing a transaction 


\section{The ruling of the Court}

In light of the clarifications just provided with regard to the legal background of the case, it is possible to better deal with the findings of the Court. Indeed, the ECJ replies to the preliminary questions by means of a systematic interpretation of article 7 EUMR.

Generally speaking, the Court held that KPMG DK Companies did not violate the standstill obligation.

More specifically, the Court acknowledges that article 7 of the EUMR does not give any indications as to the circumstances under which a concentration is deemed to be implemented and therefore this provision does not in itself clarify the scope of the prohibition it lays down. ${ }^{52}$ This is why giving an answer to the preliminary questions submitted by the Referring Court requires a systematic interpretation of article 7 EUMR based on its purpose and general scheme rather than on its literal meaning.

That said, the ECJ recalls that, as specified under recital 34 of the EUMR, the standstill obligation laid down under article 7 of the EUMR and the ex ante merger notification system adopted in the EU are aimed at ensuring an effective merger control..$^{53}$ For these purposes, article 7 of the EUMR limits the standstill obligation only to concentrations as defined under article 3 of the EUMR; it follows that all those transactions which do not contribute to the implementation of a concentration do not fall into the scope of application of article 7 EUMR. ${ }^{54}$

The Court then emphasises that a concentration is deemed to arise where there is "a change of control on a lasting basis" (see paragraph 3.1): this implies that "a concentration within the meaning of article 7 arises as soon as the merging parties implement operations contributing to a lasting change in the control of the target undertaking". ${ }^{55}$

\footnotetext{
agreement and closing the transaction in order to preserve its value are both common and appropriate in commercial transactions", in the present case it concluded that the rights obtained extended beyond what is necessary for value preservation.

${ }^{52}$ See Judgment of 31 May 2018, Ernst \& Young P/S v. Kokurrencerådet, C-633/16, EU:C:2018:371, paragraph 38 .

${ }^{53}$ See Judgment of 31 May 2018, Ernst \& Young P/S v. Kokurrencerådet, C-633/16, EU:C:2018:371, paragraph 42.

${ }^{54}$ See Judgment of 31 May 2018, Ernst \& Young P/S v. Kokurrencerådet, C-633/16, EU:C:2018:371, paragraph 49.

${ }^{55}$ See Judgment of 31 May 2018, Ernst \& Young P/S v. Kokurrencerådet, C-633/16, EU:C:2018:371, paragraph 46.
} 
Otherwise, the effet utile of article 7 EUMR would be reduced if the merging parties were prohibited from implementing a concentration by means of a single transaction, but could circumvent the prohibition through successive partial operations. This would also hamper the functioning of the prior notification system designed by the EUMR.

The ECJ also makes reference to recital 20 of the EUMR, ${ }^{56}$ according to which it is appropriate to treat as a single concentration transactions that are closely connected in that they are linked by condition or take the form of a series of transactions in securities taking place within a reasonably short period of time. Indeed, where such transactions, despite having been carried out in the context of a concentration, are not necessary to achieve a change of control of an undertaking concerned by that concentration, they do not fall within the scope of article 7 EUMR. Such transactions, although they may be ancillary or preparatory to the concentration, do not present a direct functional link with its implementation, so that their implementation is not, in principle, likely to undermine the efficiency of the control of concentrations.

This is maybe one of the most important statements of the Decision, also in light of the applicative problems described under paragraph 3.2: as noted ${ }^{57}$ the ECJ emphasises that a broader interpretation of article 7 EUMR would be incompatible with the merger control system, i.e. "extending the scope of article 7(1) to the actions that do not meet the 'contributing to the change in control' test would breach article 1 of the EUMR that sets the ambit of the Commission regulatory jurisdiction on mergers". Indeed, "an extensive interpretation of article 7(1) would also correspondingly reduce the reach of Regulation (EC) No. 1/2003 and of article 101 TFEU".

The fact that such transactions may produce effects on the market is not in itself sufficient to justify a different interpretation of article 7 EUMR. Indeed, first of all the assessment of a transaction's effects on the market falls within the substantive examination of a concentration and does not impinge on the notion of concentration. The standstill obligation laid down by article 7 EUMR applies irrespectively of whether or not the merger is compatible with the common market. Second, it cannot be ruled out that a transaction having no effect might nevertheless contribute to the change

\footnotetext{
${ }^{56}$ See Judgment of 31 May 2018, Ernst \& Young P/S v. Kokurrencerådet, C-633/16, EU:C:2018:371, paragraph 48 .

${ }^{57}$ Giannino, "Is it too early wrong? The Court of Justice of the EU clarifies the concept of gunjumping”, 10.
} 
in control of the target undertaking and that therefore, at least partially, it implements the concentration.

It follows that, according to the Court, article 7 EUMR must be interpreted as prohibiting the implementation by the parties to the concentration of any transaction which contributes to lasting change of control over one of the undertakings concerned by the transaction.

The ECJ ends up pointing out that such an interpretation is fully coherent with the general scheme of the EUMR. Indeed, such Regulation forms part of a legislative whole intended to complement articles 101 and 102 TFEU and to establish a system aimed at ensuring that competition is not distorted in the internal market. Therefore, extending the scope of article 7 EUMR to transactions not contributing to the implementation of a concentration would amount to extending the scope of the regulation in breach of article 1 thereof, but also to correspondingly reducing the scope of Regulation 1/2003, which would then no longer be applicable to such operations, even if they may give rise to coordination between undertakings for the purposes of article 101 TFEU.

In light of the foregoing, it must be concluded that article 7 EUMR must be interpreted as meaning that a concentration is implemented only by a transaction which, in whole or in part, in fact or in law, contributes to the change in control of the target undertaking.

As for the case at stake, this means that the EY companies have not acquired the possibility of exercising any influence over the KPMG DK Companies by that termination, as is apparent from the fact that the latter companies were, in the context of competition law, independent both before and after that termination. This was the case despite the fact that the merger agreement expressly provided for the KPMG DK Companies' withdrawal from the cooperation agreement. Thus, even though, absent the concentration, the KPMG DK Companies would likely not have terminated the agreement, the termination itself did not confer to the KPMG DK Companies' counterpart any possibility to exercise influence over the KPMG DK Companies.

\section{Conclusive remarks}

As anticipated, the Decision was long awaited by scholars, professionals and market players. Indeed, scholars were ready to welcome the first case ever in which the ECJ was called to give a systematic answer to one of the most controversial and less studied topics of EU merger control. On the 
other hand, professionals and market players were eager to receive clarifications on a costly and time consuming issue, with relevant impact on the management of complex transactions.

From a certain point of view, no one should be disappointed by the outcome of the Decision.

From an academic point of view, also thanks to the contribution of the AG, the Court has given a clear and precious overview of the EU merger control system as a whole and has managed to reconcile several different notions like the ones of concentration, control and standstill, bringing them to unity in a magisterial way. At a closer look, this was the only possible outcome given the grounds on which both the AG and Court based their work: a positive definition of what amounts to procedural gun jumping (meaning an analytical and exhaustive list of acts) would not be efficient and therefore one should make use of a negative definition. A negative definition may work only if it is conceptually well-tailored and coherent with the EU merger control system and that is unequivocally true in the Decision, which appears to be well argued and justified.

Another interesting aspect from an academic perspective is the fact that the ECJ points out that applying the merger control provisions to actions that do not contribute to a change of control but are nevertheless capable of leading to co-ordination could fall under the scope of the antitrust rules when they do not fall within the scope of merger control rules. This is relevant insofar as it helps strengthening the idea that EU competition law is a coherent and unitary system.

From a practical point of view, the Court has surely confirmed that premerger assessment will have to be carefully carried out by companies willing to enter into notifiable transactions. Moreover, the ECJ has surely given some kind of clarifications regarding the way in which pre-merger analysis will have to be carried out. On the other hand, as noted, ${ }^{58}$ the Decision indicates that the perimeter of gun-jumping prohibition is not infinitely elastic, as its scope is functionally connected to the concept of concentration, to the effect that the reach of the standstill obligation could not go beyond the purview of the Commission's jurisdiction on mergers as determined by article 1 of the EUMR. This also represents a useful contribution

\footnotetext{
${ }^{58}$ Giannino, "Is it too early wrong? The Court of Justice of the EU clarifies the concept of gunjumping”, 10.
} 
to the solution of the "minority shareholding acquisition" issue described under paragraph 3.2, as some authors envisaged back in $2010 .{ }^{59}$

Nevertheless, the test provided in the Decision still appears to be quite vague, so that further clarification would be appreciated. In this respect, to a closer look it seems that problem lays in the fact that the ECJ linked the notion of standstill pursuant to article 7 EUMR to the one of concentration, which is linked to the notion of control. As seen (see paragraph 3.1), the notion of control is quite broad as it includes de facto control. Put differently, it seems that the Decision may risk to shift the problem from the concept of standstill to the one of de facto control, which is in itself quite broad and vague.

But again, at a closer look this was the only possible outcome given that both the AG and the Court refused the possibility to make reference to a "positive" definition of gun jumping acts.

Finally, one should not underestimate the implications of the statement under which articles 101 and 102 TFEU shall be applied to actions that do not contribute to a change of control but are nevertheless capable of leading to co-ordination. Indeed, this may help in giving an answer to another very controversial issue in EU merger control, which is the potential investigation of consummated and non-notifiable mergers, since they fall below the notification thresholds of any merger control system, or since there was no obligation to report the transaction (e.g. because the notification system has exceptions or is voluntary). Although a careful examination of this topic would exceed the limits of the present contribution, suffice it to say that if by their very nature articles 101 and 102 TFEU shall be applied to actions that do not contribute to a change of control, it may be possible to argue that a competition authority may in any case resort to general antitrust provisions on horizontal agreements and unilateral conduct or abuse of dominance also in case of non-notified mergers.

\section{Bibliography}

Alomar, Bruno, Sophie Moonen, Gorka Navea and Philippe Redondo. "Electrabel/CNR:

The importance of the standstill obligation in merger proceedings". Competition Policy Newsletter 3 (2009).

Beretta, Matteo and Marco d'Ostuni. Il Sistema del Controllo delle Concentrazioni in Italia. Torino: Giappichelli, 2018.

\footnotetext{
${ }^{59}$ Depoortere and Lelart, "The standstill obligation in the ECMR", 119.
} 
Carloni, Francesco. "Electrabel v. Commission \& COMP M.7184 Marine Harvest/ Morpol: Gun-jumping and violation the merger standstill obligation in Europe". Journal of European Competition Law and Practice 5, no. 10 (2018): 693-696.

Cook, John and Cristopher S. Kerse. EC Merger Control. London: Sweet \& Maxwell, 2009.

Depoortere, Frederic and Stephane Lelart. "The standstill obligation in the ECMR", World Competition 33, no. 1 (2010): 103-120.

Dionnet, Stéphane and Pauline Giroux. “Gun jumping”, 2017, https://www.skadden. com/-/media/files/publications/2017/01/gun_jumping.pdf.

European Commission. Commission Consolidated Jurisdictional Notice under Council Regulation (EC) No. 139/20017 on the control of concentrations between undertakings, 2008/C 95/01, April 16. 2008, https://eur-lex.europa.eu/legal-content/EN/ALL/?uri=C ELEX\%3A52008XC0416\%2808\%29.

European Commission. White Paper towards more effective EU merger control, COMP (2014) 449 final, July 9, 2014. http://ec.europa.eu/competition/consultations/ 2014_merger_control/mergers_white_paper_en.pdf.

European Commission. XXXI Report on Competition Policy 2001,2002. http://ec.europa. eu/competition/publications/annual_report/2001/en.pdf.

Fattori, Piero and Mario Todino. La Disciplina della Concorrenza in Italia. Bologna: Il Mulino, 2010.

Giannino, Michele. "Is it too early wrong? The Court of Justice of the EU clarifies the concept of gun-jumping", 2018, https://papers.ssrn.com/sol3/papers.cfm?abstract_ $\mathrm{id}=3236909$.

Kadar, Massimiliano. "Case T-704/14 - Marine Harvest v. Commission: On 'gun jumping' and public bids". Journal of European Competition Law and Practice 9, no. 4 (2018): 239-242.

Levy, Nicholas and Cristopher Cook. European Merger Control Law. New York: LexisNexis.

Missanelli, Pietro. “La portata dell'obbligo di stand-still di cui all'art. 7, Regolamento (CE) 139/2004 nel periodo antecedente all'autorizzazione di una concentrazione tra imprese”. Diritto del Commercio Internazionale 3 (2018).

Modrall, James R. and Stefano Ciullo. "Gun-jumping and EU merger control”. European Competition Law Review 24, no. 9 (2003): 424-430.

Whish, Richard and David Bailey. Competition Law. Oxford: Oxford University Press, 2015. 